Operations Research and Applications : An International Journal (ORAJ), Vol.4, No.2, May 2017

\title{
Application Of GoAl Programming APPROACH ON FINDING AN OPTIMAL LAND AlLOCATION FOR FIVE OTHER FIELD CROPS IN ANURADHAPURA DISTRICT
}

\author{
Anuradha Gamage \\ Department of Economics, University of Ruhuna, Sri Lanka
}

\begin{abstract}
Agriculture is the main contribution to the rural economy of Sri Lanka. This study is carried on finding optimal land allocation for cultivation using goal programming approach. Five crops namely Cowpea, Black gram, Finger Millet, Maize and Soya Bean were selected to the study. This land allocation is for Anuradhapura District since it is the major agricultural district in Sri Lanka. Preemptive Goal Programming method is used in finding the optimal land allocation. Three goals are considered according to their priorities to seek the optimal solution. MS Excel Solver is used to implement the linear model. The data was collected from Annual Reports of Department of Agriculture. According to the final results obtained by goal programming approach, all five crops are reached their expected production. But the extent in yala(Dry Season) and maha(Rainy Season) season is changed. Overall result shows that new allocation exceeds the production and profit as well as minimizing the production cost. This mathematical model can easily be used on any other crop in any district by changing the variable coefficients and constraint values.
\end{abstract}

\section{KEYWORDS}

Land Allocation, Maha Season, Other field Crops, Preemptive Goal Programming, Yala Season

\section{INTRODUCTION}

\subsection{BACKgRound OF THE STUdy}

Sri Lanka is an agriculture based country since ancient times. People used to cultivate their food at those times. After a long period people started cultivation not only for their consumption but for others consumption. Money took the most important place and everything changed around money. In this study it is going to analyze what sort of methods we can use to increase the profit. Agriculture is the main stay of the rural economy of Sri Lanka. It employed about 34\% of the labor force and contributed 19\% of GDP in 2014. The agricultural sector engages a major share of the natural resources of the country and high growth in this sector is crucial to alleviate poverty and ensure food security as well as develop economic activities in rural areas.

Five other field crops namely Black gram, Cowpea, Finger Millet, Maize and Soya Bean were selected to the study considering their contribution to the economy (import substitution and etc.)and farmer income .This study is done considering Anuradhapura District as it is one of the few district in the dry zone of sri lanka where secondary crops(other field crops) are cultivated extensively. This survey is done on finding optimal land allocation for cultivating the selected crops in both yala and maha seasons. 
Table 1.1:- Contribution by each production to the national in Anuradhapura

\begin{tabular}{|l|l|} 
Black gram & 35.3 \\
\hline Cowpea & 9.4 \\
\hline Finger Millet & 28 \\
\hline Maize & 20.7 \\
\hline Soya Bean & 32 \\
\hline
\end{tabular}

\subsection{IMPORTANCE OF ThE STUdY}

Considerable amount of yield is wasted due to many reasons in each year in Anuradhapura. Sometimes the production is larger than the total demand. If farmer is unable to sell the yield, he will sell it in low prices or destroy it. Especially in the maha season farmers regularly face this problem. During maha season cultivation is done using rain water.so In that season paddy cultivation is higher. But in yala season most of farmers don't cultivate paddy, they cultivate some of secondary crops instead of paddy. This study searches for the suitable land allocation for those secondary crops in both seasons which will help farmer to increase the production as well as the profit.

Most of farmers in Anuradhapura district use more man power than the machine power. Therefore they have to spend a large amount of money higher than they spend for machine power. Excluding family labor, farmers need more man power in every stage of cultivation. Even though they get a high production they are not able to get a good profit. This study concern about it too. Government has taken many steps in order to develop secondary crop cultivation in Anuradhapura. FCRDI handles all those projects. FCRDI has set up a plan for year 2015 for secondary crop production. This project follows those targets. Results of this may help to achieve those goals.

\subsection{ObJeCtives Of THE STUdy}

Main objective of this study is setting up a land allocation for the selected five crops. There are three other sub goals in this survey which lies beyond this land allocation.

- First Goal is to maximize the production. Amount of land cultivated should give a maximum production.

- Second is maximizing the net profit.

- Third is minimizing the laboring cost.

- Fulfill the targets established by FCRDI for the year 2015.

\subsection{Limitations Of The STUdY}

This study is not going to increase the total amount of land cultivating in Anuradhapura district. Land allocation method is applied to the available land cultivated lands in Anuradhapura. Therefore it is set that each crop extent should not exceed the amount of land cultivated in year 2014.

E.g.: Amount of land for maize in Yala $2015=a$

Amount of land for maize in maha 2015=b

Total Amount of land cultivated in both seasons in 2014=A

Therefore $\mathrm{a}+\mathrm{b}<=\mathrm{A}$ 
Operations Research and Applications : An International Journal (ORAJ), Vol.4, No.2, May 2017

THE TOTAL AMOUNT OF YIELD SHOULD EXCEED THE LAST YEAR (2014) YIELD AND ALSO TO FULFILL THE DEMAND in yala season each crop should yield more than pre calculated amount which is set by considering the contribution to the national consumption by Anuradhapura district.

Government supplies aids for fertilize and seeds. So the total cost in Anuradhapura district should be less than the amount allocate for the district. Labor cost, seeds cost and the fertilize cost are only considered as the cost of production. Here it is assumed that the production is sold at the farm gate without doing anything to the yield. So the transportation cost, storage cost and other relevant cost are not considered

\section{LITERAURE REVIEW}

\subsection{INTRODUCTION}

This chapter contains the related studies done on optimal land allocation using goal programming approach.

\subsection{RELATED STUdies}

Dinesh K. Sharma et al (2007) have done a survey on fuzzy goal programming for agricultural land allocation problems in India. That paper presents optimal allocation of land under cultivation and proposes an annual agriculture plan for different crops on India. In the formulation goals such as crop production, net profit, water and labor requirement and machine utilization are modeled as fuzzy.

D.Latinopoulos and Y.Mylopoulos (2005) have published a research paper on optimal allocation of land and water resources in irrigated agriculture by means of goal programing based on the loudias river basin in Greece. The main objective of this survey is to create, evaluate and apply a model that aims at the simultaneous maximization of farmers' welfare and consequent environment burden. Weighted and goal programming techniques are applied to seek for a compromising solution in terms of area and water allocation under different crops.

Korea Forest Research Institute (2009) has published a research paper on Applications of Goal Programming for Optimization of Carbon Sink in Youngdong-gun in Korea which seeks for land allocation in forest area. The institute has launched a project on planting oak trees in forest area in order to manage carbon sink. The research based on 4 goals goal programming approach is used to reach the goals.

\section{THEORY AND METHOdOLOGY}

\subsection{INTRODUCTION}

This chapter describes the theory used to reach the objectives and the methodology used to implement the model and solve it.

\subsection{Goal Programming Approach}

In real life all problems have several variables, not just one. A goal programming model seeks for achieving several goals simultaneously while the linear programming seeks to fulfill single objective. These kinds of goal programming models consist of constraints and a set of goals that are prioritized in some sense. The models which consist of prioritized goals are known as preemptive goal programming. This approach analyzes how much a proposed solution deviates from each goal. Therefore pair of deviation variables is defined for each goal. 


\subsection{DEVIATIONAL VARIABLES}

If failure to meet goal I occurs when the attend value of attribute is numerically smaller than the desired value of goal $i$, then a term involving $\mathrm{S}_{\mathrm{i}}^{-}$will appear in objective function. If failure to meet goal $i$ occurs when attended value of an attribute is numerically larger than the desired value of goal $\mathrm{i}$, then a term involving $\mathrm{S}_{\mathrm{i}}^{+}$will appear in the objective function.

$\mathrm{S}_{\mathrm{i}}^{+}=$Amount by which the $\mathrm{i}^{\text {th }}$ goal level is exceeded.

$\mathrm{S}_{\mathrm{i}}^{-}=$Amount by which the $\mathrm{i}^{\text {th }}$ goal level is under achieve.

These $\mathrm{S}_{\mathrm{i}}^{+}$and $\mathrm{S}_{\mathrm{i}}^{-}$are referred as deviational variables which should be minimized.

\subsection{Preemptive Goal Programming}

In many situations a decision maker may not be able to determine precisely the relative important of the goal. When this is the case preemptive goal programming (PGP) may prove to be a useful tool. To apply PGP the decision maker must rank her/his goal from the most important to least important.

$\mathrm{P} 1>>>>\mathrm{P} 2>>>>>\ldots \ldots \ldots \ldots . .>\mathrm{Pn} ; \mathrm{Pi}=$ weight of the goal.

\subsection{METHODOLOGY}

The FCRDI has established targets to cover in the year 2015 in Anuradhapura district. They are as follows,

Table 3.1: Targets in 2015

\begin{tabular}{|l|l|l|l|l|}
\hline \multirow{2}{*}{ crop } & \multicolumn{2}{|l|}{ Yala } & Maha \\
\cline { 2 - 5 } & Extent(ha) & Yield (Mt) & Extent(ha) & Yield (Mt) \\
\hline Black gram & 510 & 655 & 6750 & 6344 \\
\hline Cowpea & 355 & 402 & 2130 & 2568 \\
\hline Finger Millet & 210 & 194 & 2675 & 2693 \\
\hline Maize & 2310 & 7105 & 32500 & 85965 \\
\hline Soya Bean & 3600 & 6531 & 1225 & 2018 \\
\hline
\end{tabular}

As this project seeks for an optimal land allocation which maximizes production and the profit, it is essential to consider these targets as well.

Table 3.2: Costs and Pric

\begin{tabular}{|l|l|l|l|l|l|}
\hline crop & $\begin{array}{l}\text { Selling price } \\
\text { in Yala } \\
\text { season Rs/kg }\end{array}$ & $\begin{array}{l}\text { Selling price } \\
\text { in Maha } \\
\text { season } \\
\text { Rs/kg }\end{array}$ & $\begin{array}{l}\text { Cost for } \\
\text { seeds Rs/ ha }\end{array}$ & $\begin{array}{l}\text { Fertilizing } \\
\text { cost Rs/ha }\end{array}$ & $\begin{array}{l}\text { Labor cost } \\
\text { Rs/ha }\end{array}$ \\
\hline $\begin{array}{l}\text { Black } \\
\text { gram }\end{array}$ & 46 & 43 & 1249.2 & 1811.2 & 11732.8 \\
\hline Cowpea & 41 & 39 & 95902 & 1491.6 & 15411.2 \\
\hline $\begin{array}{l}\text { Finger } \\
\text { Millet }\end{array}$ & 38 & 34 & 730 & 970 & 13369.6 \\
\hline Maize & 33 & 30 & 1400 & 1411.2 & 12040 \\
\hline Soya Bean & 39 & 35 & 1370 & 2170 & 15410 \\
\hline
\end{tabular}


Operations Research and Applications : An International Journal (ORAJ), Vol.4, No.2, May 2017

According to the table 3.2 it seems that selling prices in yala season is higher than maha season because of the production is less in yala season. These are average values obtained considering past year values. There is a high difference between seed costs of finger millet and cowpea. It happens due to arrival of cowpea hybrids. Normally farmers produce finger millet seeds themselves and very rarely buy them. Usually 41 man days are needed to work in 1 hectare of maize which costs about Rs 734 per day. This is an average value for both seasons. Man power is highly consumed in watering and fertilizing. Since the farmers in Anuradhapura barely use machine power in secondary crop cultivation they need more man power.

The objectives of this study can be written as,

Goal 1: Maximizes the total production in both seasons

Goal 2: Maximizes the total net profit in both seasons

Goal 3: Minimizes the cost spends on labor.

$\mathrm{X}_{\mathrm{ij}}$--Amount of cultivating area ( $\mathrm{i}=\mathrm{crop}, \mathrm{j}=$ season)

They also can be kept in order to the priority, Goal1 >>Goal2 >>Goal3.

This means whenever the second goal is going to be satisfied the first goal must be satisfied. We can satisfy third goal only after satisfying the both first and second goals. The total production should at least be more than $114475 \mathrm{Mt}$ in order to fulfill the contribution.

The second goal is about the net profit, in this study the farm gate price is considered and it is assumed that harvest is directly sold out. Therefore the net profit is calculated as follows,

Net profit/ha $=($ Average yield*Area*Selling price) - (seed cost*area) - (fertilizing cost*area) (Labor cost*area)

According to the previous years' data, net profit should be at least Rs. 2,850,000,000. These were calculated by considering the farmers registered in the FCRDI. FCRDI has estimated that total labor cost is Rs $655,000,000$. So when minimizing it this value should not be exceeded.

For the better results these constraints were set.

1 Land cultivates in Yala season should not exceed 6985 ha.

2 Land cultivates in Maha season should not exceed 45280 ha.

3 Total production of each crop in both seasons should at least reach the pre-defined value. This value is obtained by the national consumption of each crop and the contribution given by Anuradhapura yield.

4 In maha season production of these crops are less, so there is a certain limit to production in that season which should be definitely passed through.

5 Total fertilizing cost can be fulfilled by the amount lend by government.

Using these objectives and constraint PGP is modeled. It is implemented in MS EXCEL and solved by EXCEL solver.

\subsection{MATHEMATICAL MODEL}

$\mathrm{X}_{\mathrm{ij}} \mathrm{i}=1 \_5,(1=$ Cowpea,2=Black Gram,3=Finger millet, 4=Maize,5=Soya Bean)

$\mathrm{j}=1 \_2(1=$ season $1,2=$ season 2$)$

Goal1: (maximize production)

$1.1 \mathrm{X}_{11}+1.21 \mathrm{X}_{12}+1.3 \mathrm{X}_{21}+1.34 \mathrm{X}_{22}+1.1 \mathrm{X}_{31}+1.15 \mathrm{X}_{32}+3.68 \mathrm{X}_{41}+3.98 \mathrm{X}_{42}+1.5 \mathrm{X}_{51}+1.58 \mathrm{X}_{52}$ 
Operations Research and Applications : An International Journal (ORAJ), Vol.4, No.2, May 2017

Goal2: (maximize net profit)

$35806 \mathrm{X}_{11}+32506 \mathrm{X}_{12}+35438 \mathrm{X}_{21}+32838 \mathrm{X}_{22} \quad+26730 \mathrm{X}_{31}+22330 \mathrm{X}_{32}+116489 \mathrm{X}_{41}$ $+104549 \mathrm{X}_{42}+39550 \mathrm{X}_{51}+33550 \mathrm{X}_{52}$

Goal3: (Minimize Labor cost)

$11733 \mathrm{X}_{11}+11700 \mathrm{X}_{12}+15411 \mathrm{X}_{21}+15400 \mathrm{X}_{22}+13370 \mathrm{X}_{31}+13300 \mathrm{X}_{32}+12040 \mathrm{X}_{41}$

Constraints:

$1 \mathrm{X}_{11}+\mathrm{X}_{21}+\mathrm{X}_{31}+\mathrm{X}_{41}+\mathrm{X}_{51}<=6985$ (Land in Yala Season)

$2 X_{12}+X_{22}+X_{32}+X_{42}+X_{52}<=45280$ (Land in Maha Season)

$3 \quad 1.1 X_{11}+1.21 X_{12}>=6995$

$4 \quad 1.3 \mathrm{X}_{21}+1.34 \mathrm{X}_{22}>=2970$

$5 \quad 1.1 X_{31}+1.15 X_{32}>=2887$

$6 \quad 3.68 \mathrm{X}_{41}+3.98 \mathrm{X}_{42}>=93078$

$7 \quad 1.5 \mathrm{X}_{51}+1.58 \mathrm{X}_{52}>=8549$

$81811 X_{11}+1710 X_{12}+1492 X_{21}+1520 X_{22}+970 X_{31+} 955 X_{32}+1411 X_{41}+1360 X_{42}+2170 X_{51}+$ $2090 \mathrm{X}_{52}<=70,000,000+12000 \mathrm{X}_{42}+15410 \mathrm{X}_{51}+15200 \mathrm{X}_{52}$

$9 \quad 1.1 \mathrm{X}_{11}>=700$

$101.3 \mathrm{X}_{21}>=400$

$11 \quad 1.1 \mathrm{X}_{31}>=194$

$123.68 \mathrm{X}_{41}>=5000$

$131.5 \mathrm{X}_{51}>=5000$

The above model can be solved by two methods.

\subsection{DEVELOPED MODEL-METHOD 1}

After adding deviational variables (3.3) the model becomes,

Objective function

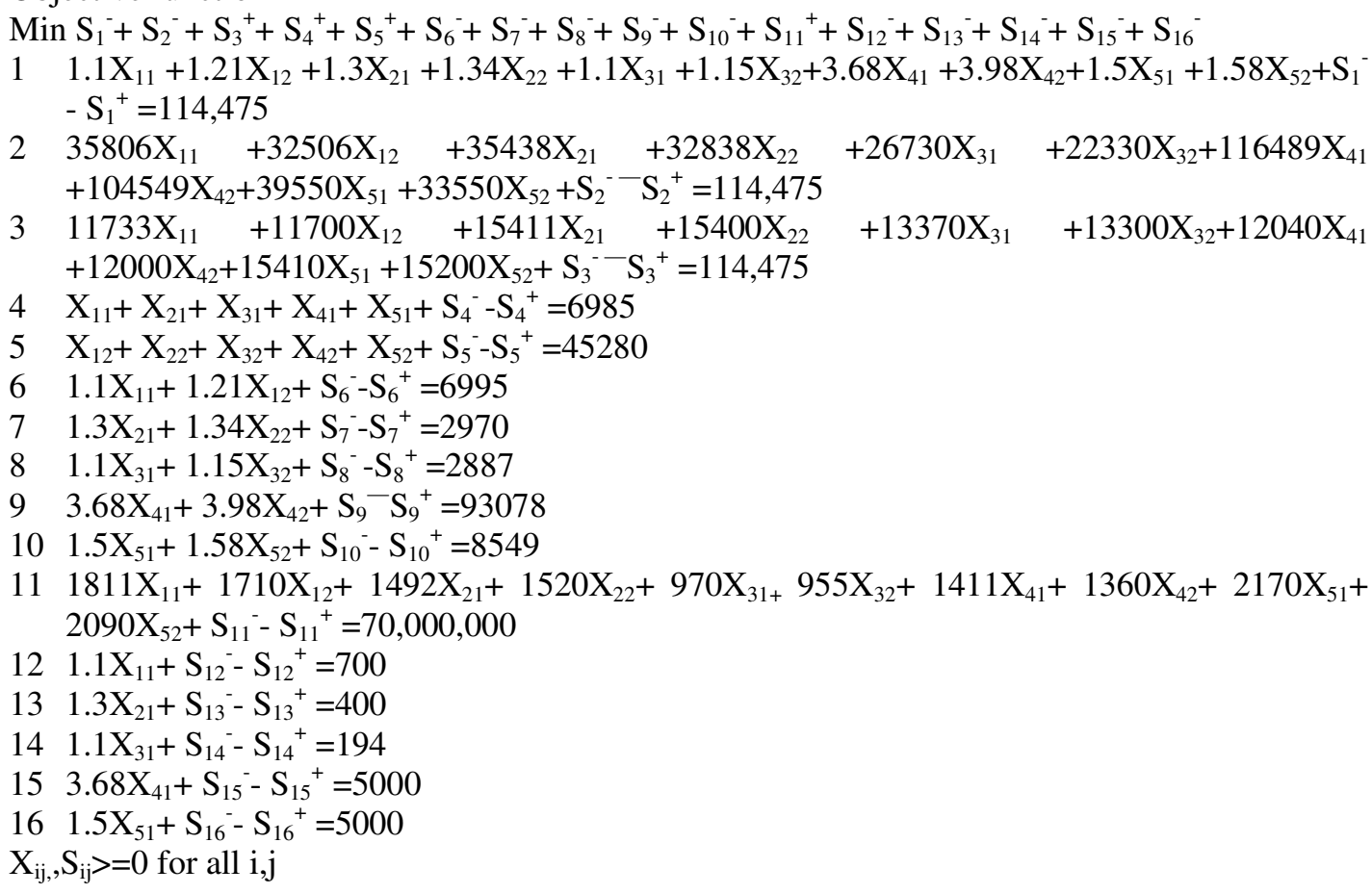


Operations Research and Applications : An International Journal (ORAJ), Vol.4, No.2, May 2017

\subsection{SOLUTIONS FOR METHOd 1 USING MS EXCEL}

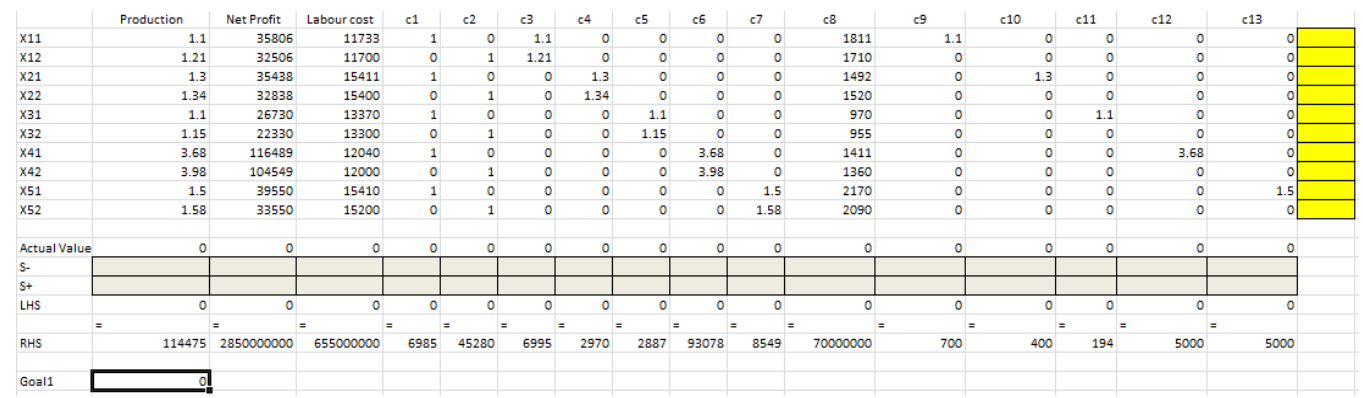

Figure 3.1: Excel worksheet implementation

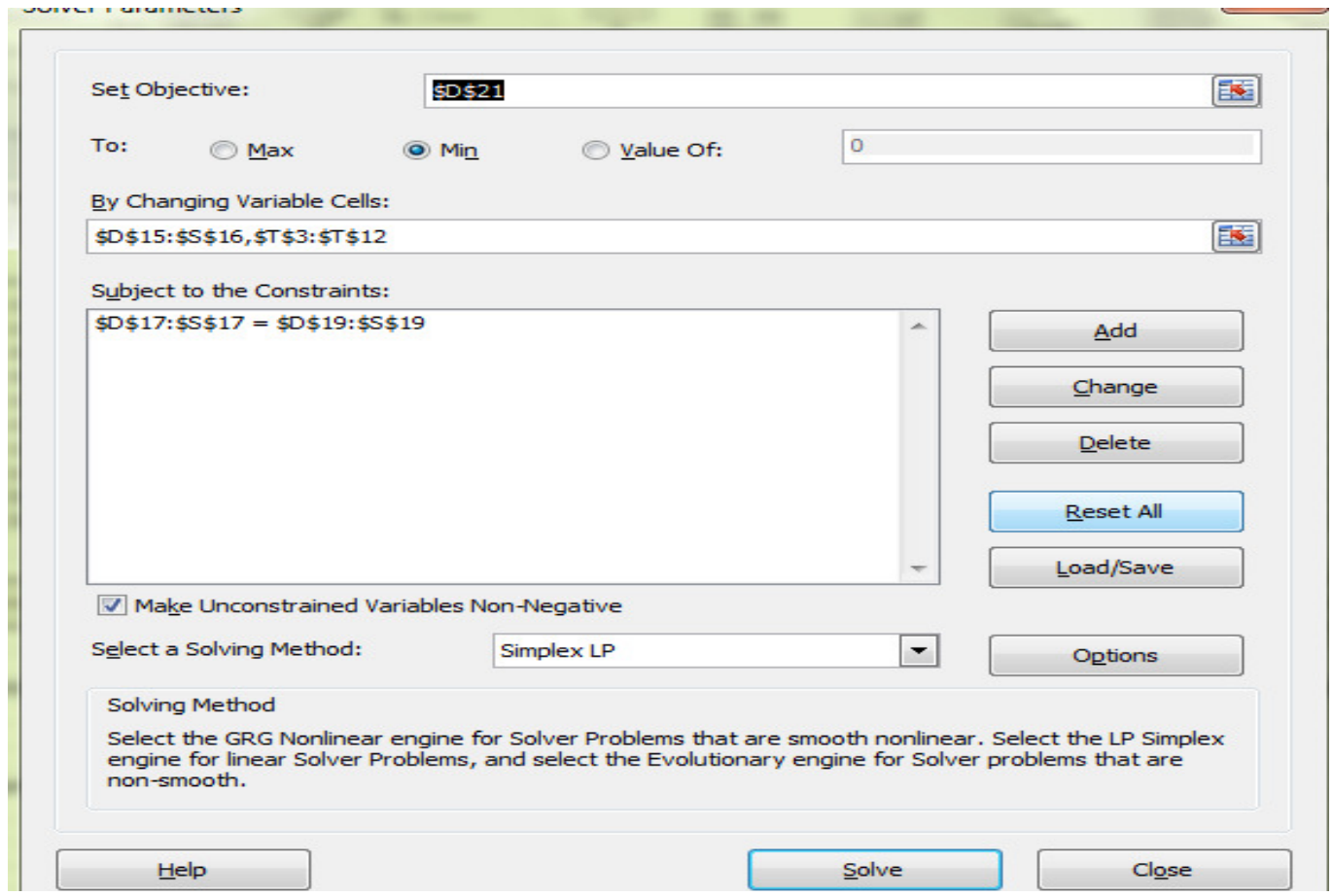

Figure 3.2: Excel Solver

Figure 3.1 presents how data is entered to the excel work sheet and Figure 3.2 shows how constraint are inserted to the solver.

\subsection{Developed model -Method 2}

Objective functions

Goal 1: Min $\mathrm{S}_{1}{ }^{-}$

Goal 2: $\mathrm{Min} \mathrm{S}_{2}$

Goal 3: $\mathrm{Min}_{3}{ }^{+}$ 
Operations Research and Applications : An International Journal (ORAJ), Vol.4, No.2, May 2017

$1 \quad 1.1 \mathrm{X}_{11}+1.21 \mathrm{X}_{12}+1.3 \mathrm{X}_{21}+1.34 \mathrm{X}_{22}+1.1 \mathrm{X}_{31}+1.15 \mathrm{X}_{32}+3.68 \mathrm{X}_{41}+3.98 \mathrm{X}_{42}+1.5 \mathrm{X}_{51}+1.58 \mathrm{X}_{52}+\mathrm{S}_{1}^{-}$ $-\mathrm{S}_{1}^{+}=114,475$

$23^{35806 X_{11}}+32506 X_{12}+35438 X_{21}+32838 X_{22}+26730 X_{31}+22330 X_{32}+116489 X_{41}$ $+104549 \mathrm{X}_{42}+39550 \mathrm{X}_{51}+33550 \mathrm{X}_{52}+\mathrm{S}_{2}{ }^{-}-\mathrm{S}_{2}{ }^{+}=114,475$

$311733 X_{11}+11700 X_{12}+15411 X_{21}+15400 X_{22}+13370 X_{31}+13300 X_{32}+12040 X_{41}$ $+12000 \mathrm{X}_{42}+15410 \mathrm{X}_{51}+15200 \mathrm{X}_{52}+\mathrm{S}_{3}{ }^{-}{ }^{-} \mathrm{S}_{3}{ }^{+}=114,475$

$4 \mathrm{X}_{11}+\mathrm{X}_{21}+\mathrm{X}_{31}+\mathrm{X}_{41}+\mathrm{X}_{51}<=6985$

$5 \quad X_{12}+X_{22}+X_{32}+X_{42}+X_{52}<=45280$

$6 \quad 1.1 X_{11}+1.21 X_{12}>=6995$

$7 \quad 1.3 \mathrm{X}_{21}+1.34 \mathrm{X}_{22}>=2970$

$8 \quad 1.1 \mathrm{X}_{31}+1.15 \mathrm{X}_{32}>=2887$

$93.68 X_{41}+3.98 X_{42}>=93078$

$101.5 \mathrm{X}_{51}+1.58 \mathrm{X}_{52}>=8549$

$111811 X_{11}+1710 X_{12}+1492 X_{21}+1520 X_{22}+970 X_{31}+955 X_{32}+1411 X_{41}+1360 X_{42}+2170 X_{51}+$ $2090 \mathrm{X}_{52}<=70,000,000$

$121.1 \mathrm{X}_{11}>=700$

$131.3 X_{21}>=400$

$141.1 \mathrm{X}_{31}>=194$

$153.68 \mathrm{X}_{41}>=5000$

$161.5 \mathrm{X}_{51}>=5000$

$\mathrm{X}_{\mathrm{ij},}, \mathrm{Sij}>=0$ for all $\mathrm{i}, \mathrm{j}$

\subsection{SOLUTIOnS For METHOD 2 USING MS EXCEL}

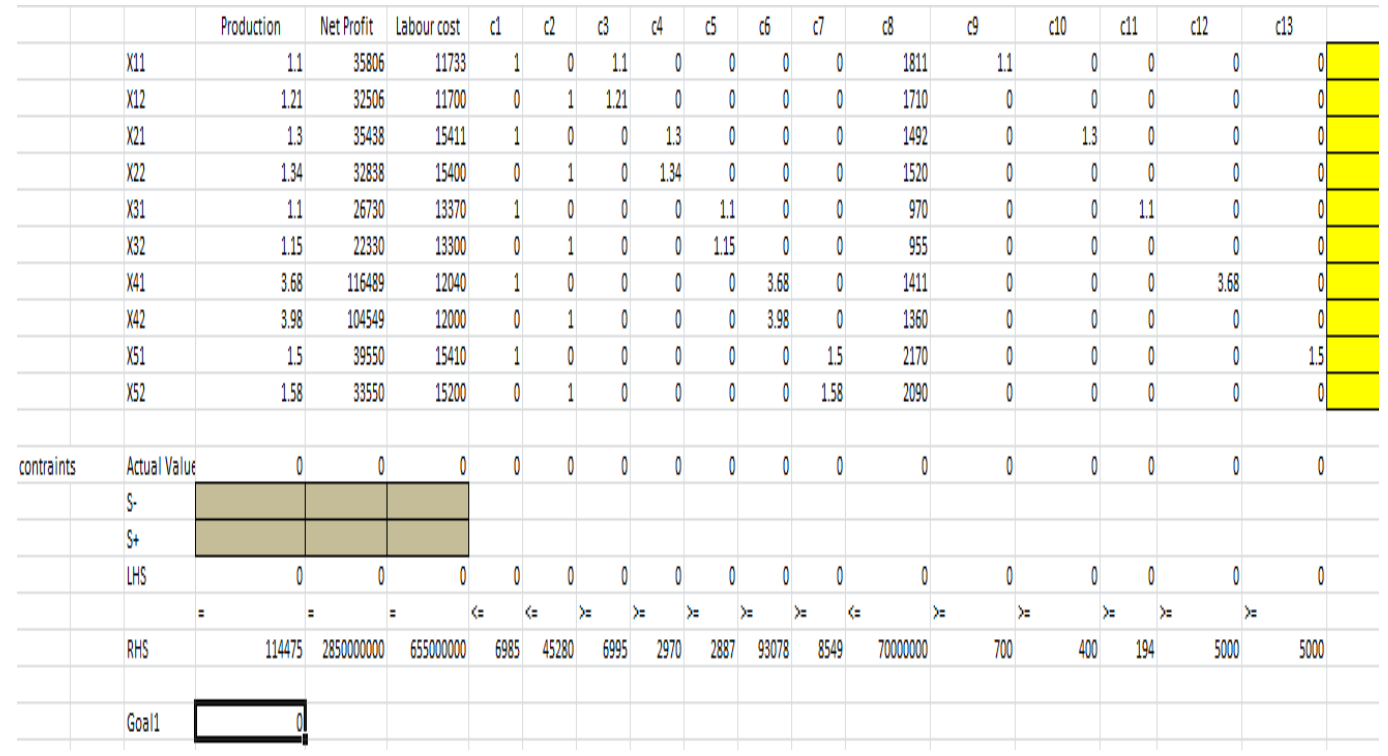

Figure 3.3: Excel Implementation for goal 1 
Operations Research and Applications : An International Journal (ORAJ), Vol.4, No.2, May 2017

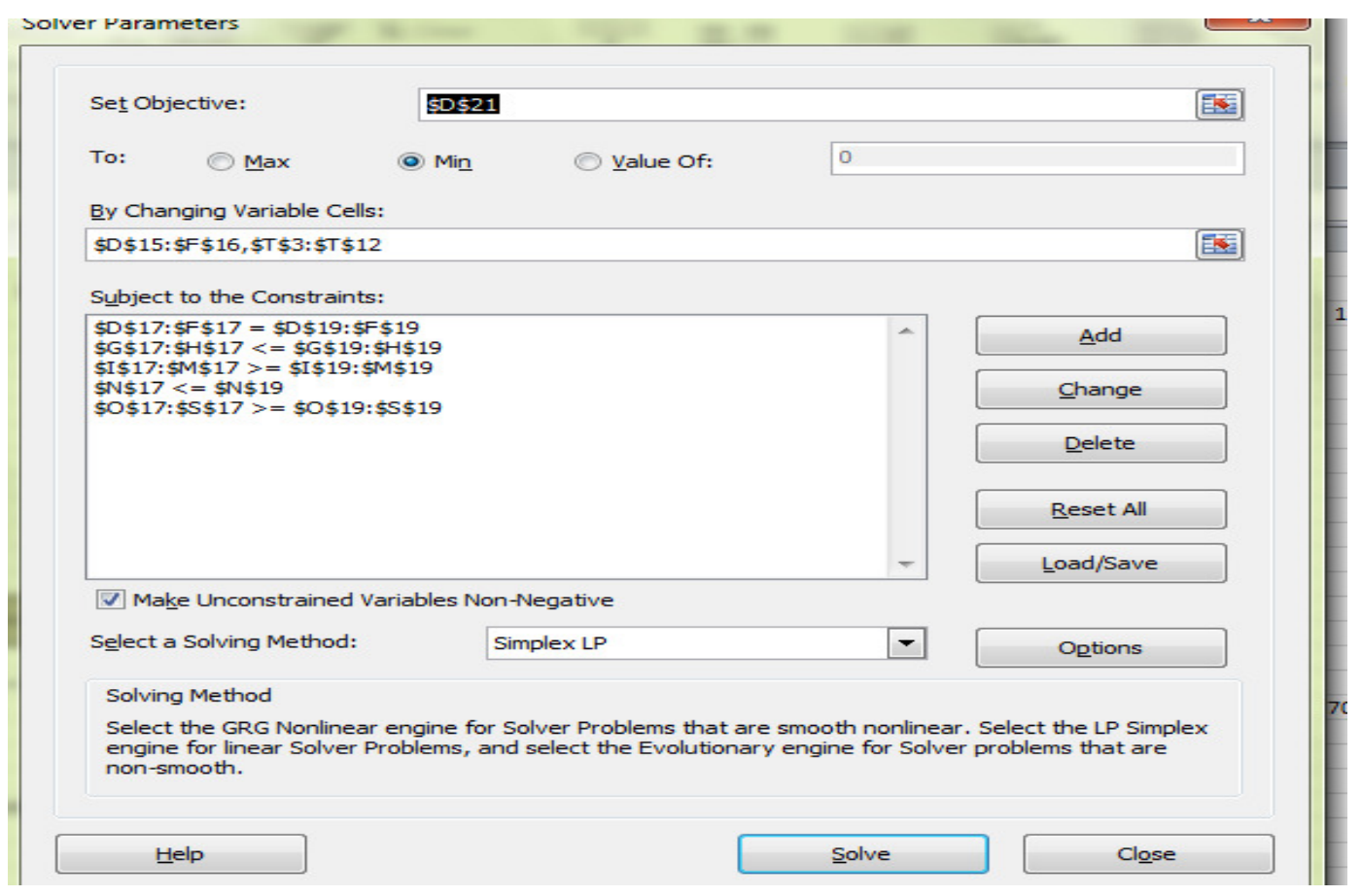

Figure 3.4 Solver model for goal 1

Figure 3.3 shows how data is entered to the excel sheeet,and the way changing vadiables are selected. Figure 3.4 shows how constraints are selected.

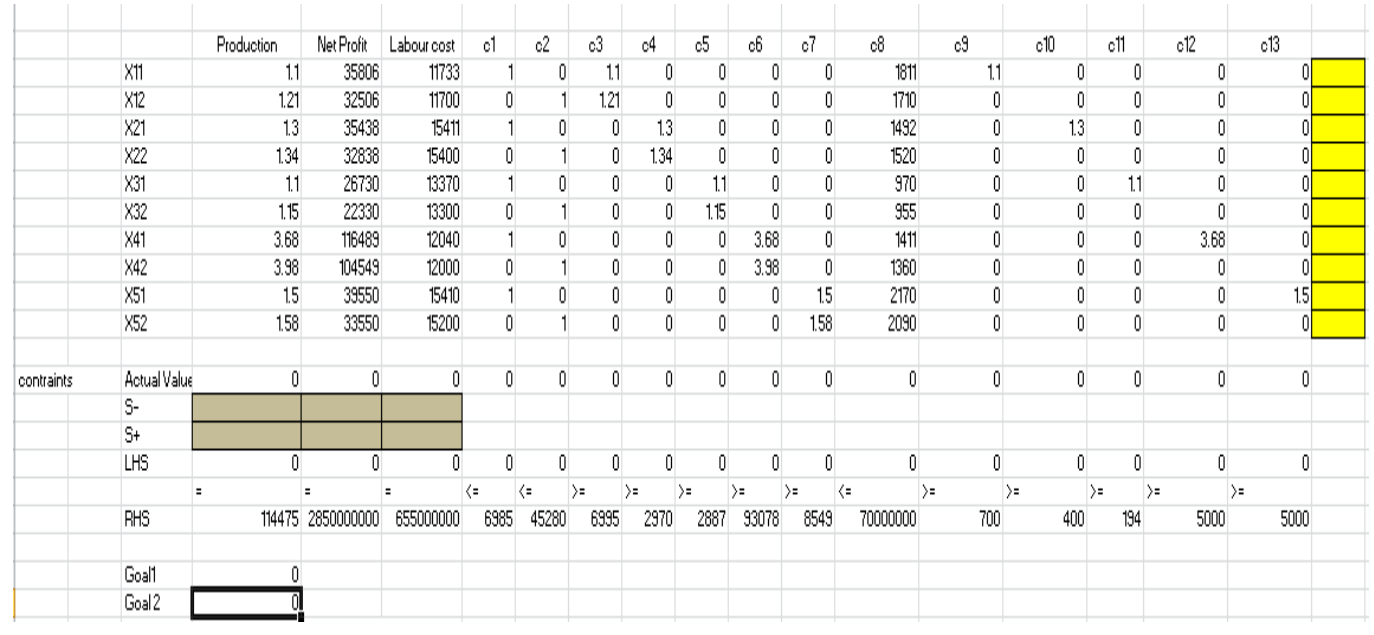

Figure 3.5: Excel Implementation for goal 2 
Operations Research and Applications : An International Journal (ORAJ), Vol.4, No.2, May 2017

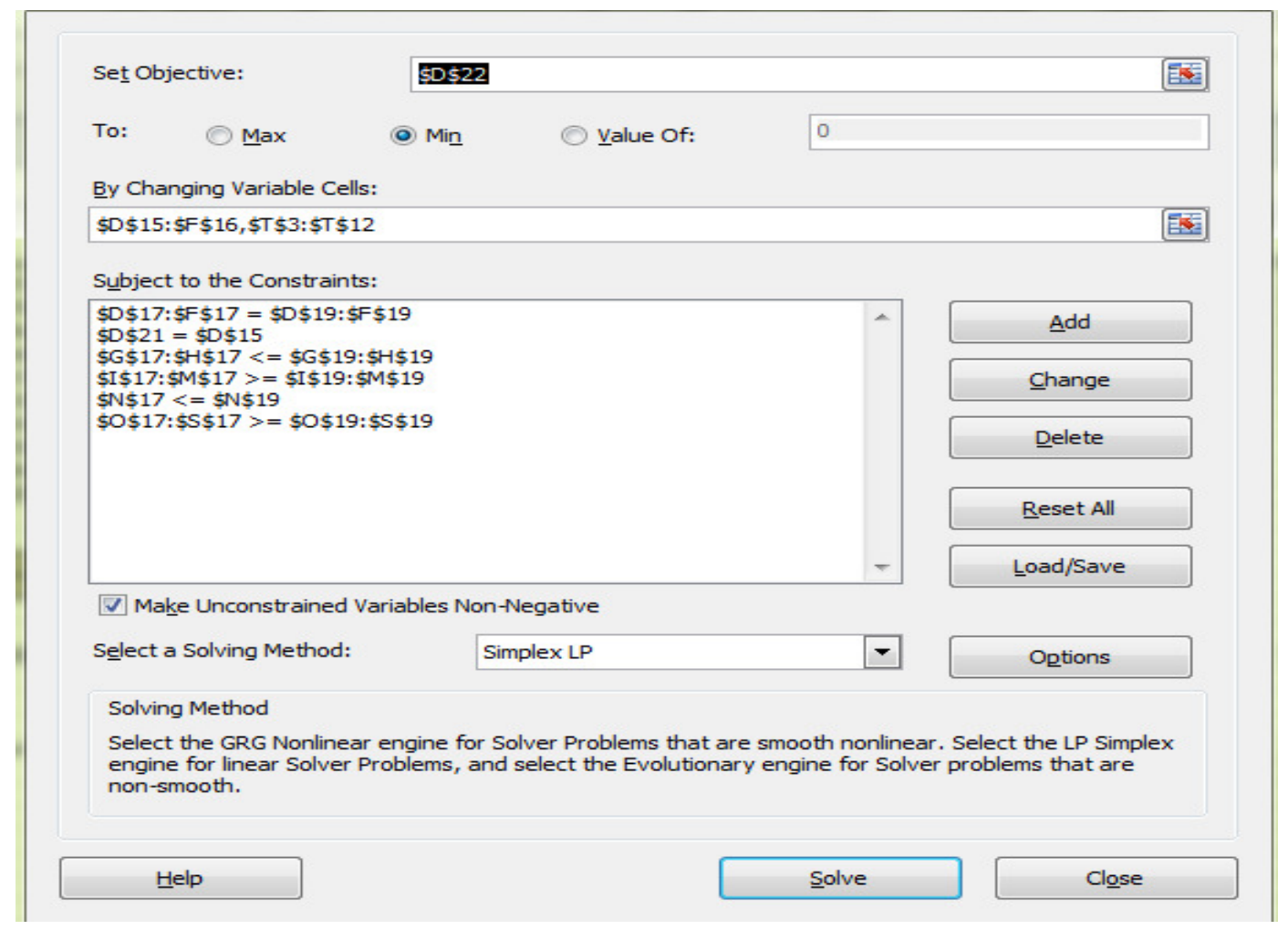

Figure 3.6: Solver model for goal 2

Figure 3.5 is similar to the figure 3.5 , but the objective cell for goal 2 is added additionally. Figure 3.6 indicates the considered constraints. Here the answer for the goal 1 is added as a constraint.

\begin{tabular}{|c|c|c|c|c|c|c|c|c|c|c|c|c|c|c|c|c|c|}
\hline & Production & Net Profit & Labour cost & c1 & c2 & $c^{3}$ & $c 4$ & $c 5$ & $c 6$ & c7 & 18 & $c 9$ & $c 10$ & c11 & c12 & c13 & \\
\hline x11 & 1.1 & 35806 & 11733 & 1 & 0 & 1.1 & 0 & 0 & 0 & 0 & 1811 & 1.1 & 0 & 0 & 0 & 0 & 636.364 \\
\hline $\mathrm{x} 12$ & 1.21 & 32506 & 11700 & 0 & 1 & 1.21 & 0 & 0 & 0 & 0 & 1710 & 0 & 0 & 0 & 0 & 0 & 5202.48 \\
\hline$x_{21}$ & 1.3 & 35438 & 15411 & 1 & 0 & 0 & 1.3 & 0 & 0 & 0 & 1492 & 0 & 1.3 & 0 & 0 & 0 & 307.692 \\
\hline$x_{22}$ & 1.34 & 32838 & 15400 & 0 & 1 & 0 & 1.34 & 0 & 0 & 0 & 1520 & 0 & 0 & 0 & 0 & 0 & 1917.91 \\
\hline x31 & 1.1 & 26730 & 13370 & 1 & 0 & 0 & 0 & 1.1 & 0 & 0 & 970 & 0 & 0 & 1.1 & 0 & 0 & 176.364 \\
\hline x32 & 1.15 & 22330 & 13300 & 0 & 1 & 0 & 0 & 1.15 & 0 & 0 & 955 & 0 & 0 & 0 & 0 & 0 & 13051.2 \\
\hline$x 41$ & 3.68 & 116489 & 12040 & 1 & 0 & 0 & 0 & 0 & 3.68 & 0 & 1411 & 0 & 0 & 0 & 3.68 & 0 & 1358.7 \\
\hline$x 42$ & 3.98 & 104549 & 12000 & 0 & 1 & 0 & 0 & 0 & 3.98 & 0 & 1360 & 0 & 0 & 0 & 0 & 0 & 22130.2 \\
\hline X51 & 1.5 & 39550 & 15410 & 1 & 0 & 0 & 0 & 0 & 0 & 1.5 & 2170 & 0 & 0 & 0 & 0 & 1.5 & 3333.33 \\
\hline x52 & 1.58 & 33550 & 15200 & 0 & 1 & 0 & 0 & 0 & 0 & 1.58 & 2090 & 0 & 0 & 0 & 0 & 0 & 2246.2 \\
\hline & & & & & & & & & & & & & & & & & \\
\hline Actual Value & 126794.8981 & 3241081278 & 645981731 & 5812.45 & 44548 & 6995 & 2970 & 15202.9 & 93078 & 8549 & 70000000 & 700 & 400 & 194 & 5000 & 5000 & \\
\hline s. & 0 & 0 & \begin{tabular}{|l|}
9018269.029 \\
\end{tabular} & & & & & & & & & & & & & & \\
\hline s+ & 12319.89811 & 391081277.9 & 0 & & & & & & & & & & & & & & \\
\hline LHS & 114475 & 2850000000 & 655000000 & 5812.45 & 44548 & 6995 & 2970 & 15202.9 & 93078 & 8549 & 70000000 & 700 & 400 & 194 & 5000 & 5000 & \\
\hline & & $=$ & $=$ & $\Leftrightarrow$ & $\Leftrightarrow$ & $=\quad x$ & & $y=$ & $=$ & $=$ & $x$ & $x$ & x & $x$ & $>$ & & \\
\hline RHS & 114475 & 2850000000 & 655000000 & 6985 & 45280 & 6995 & 2970 & 2887 & 93078 & 8549 & 70000000 & 700 & 400 & 194 & 5000 & 5000 & \\
\hline & & & & & & & & & & & & & & & & & \\
\hline Goal1 & 0 & & & & & & & & & & & & & & & & \\
\hline Goal2 & 0 & & & & & & & & & & & & & & & & \\
\hline Goal3 & 0 & & & & & & & & & & & & & & & & \\
\hline
\end{tabular}

Figure 3.7: Excel implementation for goal 3 
Operations Research and Applications : An International Journal (ORAJ), Vol.4, No.2, May 2017

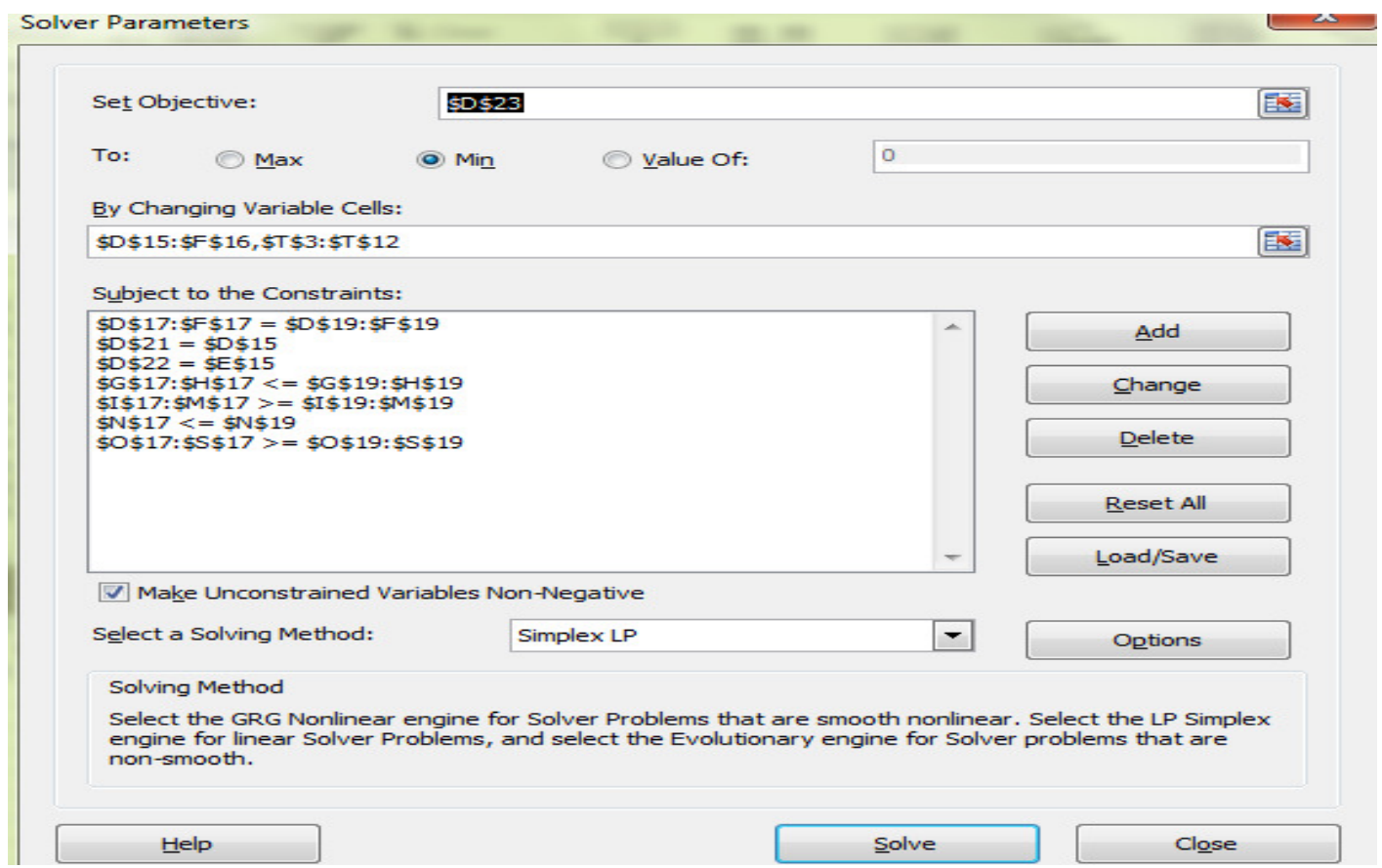

Figure 3.8: Solver model for goal 3

Figure 3.7 is similar to the figure 3.3 and figure 3.5. The only difference is adding an objective cell for goal 1. In Figure 3.8 it shows that answer for the goal 2 is added as a constraint.

\section{RESULTS}

\subsection{Results ObTained By Method 1}

Amount of Land in hectares

$$
\begin{aligned}
& X 11=636.364 \\
& X 12=5202.48 \\
& X 21=307.692 \\
& X 22=1917.97 \\
& X 31=176.364 \\
& X 32=13051.2 \\
& X 41=1538.7 \\
& X 42=22130.2 \\
& X 51=3333.33 \\
& X 52=332246.2
\end{aligned}
$$

Total Production $=126794.8981 \mathrm{Mt}$

Net Profit= Rs.3,241,081,278

Minimized Labor cost $=$ Rs 645,981,731

Values for deviational variables 
Operations Research and Applications : An International Journal (ORAJ), Vol.4, No.2, May 2017

S1-,S2-,S6-, S7-, S8-, S9-, S10-, S11-, S12-, S13-, S14-, S15-, S16-=0

S3-=9018269.029 S4-=1172.55 S5-=732.041

$\mathrm{S} 1+=12319.89811 \quad \mathrm{~S} 2+=391081277.9 \mathrm{~S} 8+=12315.9$

$\mathrm{S} 3+\mathrm{S} 4+, \mathrm{S} 5+, \mathrm{S} 6+, \mathrm{S} 9+, \mathrm{S} 10+, \mathrm{S} 11+, \mathrm{S} 12+, \mathrm{S} 13+, \mathrm{S} 14+, \mathrm{S} 15+, \mathrm{S} 16+=0$

\subsection{Results obtained by Method 2}

\section{Amount of Land in hectares}

$X 11=636.364$
$X 12=5202.48$
$X 21=307.692$
$X 22=1917.97$
$X 31=176.364$
$X 32=13051.2$
$X 41=1538.7$
$X 42=22130.2$
$X 51=3333.33$
$X 52=332246.2$

Total Production $=126794.8981 \mathrm{Mt}$

Net Profit $=$ Rs 3,241,081,278

Minimized Labor cost= Rs 645,981,731

Values for deviational variables

$\mathrm{S} 1-=0$

$\mathrm{S} 2-=0$

S3- $=9018269.029$

$\mathrm{S} 1+=12319.89811$

$\mathrm{S} 2+=391081277.9$

$\mathrm{S} 3+=0$

\section{CONCLUSIONS}

According to the results obtained by both methods it seems that both results are same although some deviational values are different.

When analyzing the each crop separately, it can be seen that every crop have reached the expected yield. FCRDI is expecting cultivate black gram in 510 hectares in Yala season and 6750 ha in Maha season. But to reach the goals, extent in Yala should be 636.36 ha and extent in Maha should be 5202.48 ha. Extent of Cowpea, Maize and Soya bean is also less than the set up values. Agriculture department and Seed Cooperation has invented new varieties of seed which gives higher yield, as result of that production can be increased even the extent is below the expectations.

The situation occurs on Finger Millet it different, although FCRDI expect to cultivate in 2675 ha in Maha season the optimal allocation is $\mathbf{1 3 0 5 1 . 2}$ ha which is five times larger than the expected extent. Actually Finger Millet is one of the high demanding crops in Sri Lanka. It has a high export value. Farmers usually produce seeds and the fertilizer consumption is somewhat low. 
Therefore production cost is low and high profit can be gained. With comparing to other crops Finger millet is one of the profitable crops.

Total production of $126794.8961 \mathrm{Mt}$ can be produced by the optimal allocation. It will give Rs $3,241,081,278$ total profit. Since the net profit is calculated considering seed cost, fertilizer cost and labor cost this value might be decreased when considering all the costs of production. Transportation cost, Storage Cost, and other costs related until the yield goes to market should be considered. There nearly 5000 small scale and large scale farmers registered in the FCRDI. Agriculture instructors can consider this land allocation and they can guide farmers how to select extent to get a high profit and production. Sometimes farmers have to throw away their yield due to very poor market. This optimal allocation will help them to select the most profitable crop in each season.

Labor cost is decreased up to Rs 645,981,731, but it can be decreased more by using machine power. Many school children work in fields in the cultivating season and harvesting season. It obstructs their education. It has been noticed that the absenteeism is high in some schools in Anuradhapura district during those periods. Regular watering systems are not established in the fields, so more human power is needed to supply water. If the farmers can build water pumps or sprayers in the field this cost will be minimized further.

\section{ACKNOWLEDGEMENT}

I would like to extend my sincere gratitude to Professor S.B.Siyambalapitiya for his guidance and supervision to handle this project. His willingness to motivate me contributed tremendously to my report. I am grateful to my parents for their guidance and unfailing encouragement to make this task success. They gave excellent ideas to handle this report. Finally I wish to thank all who helped us in numerous ways to complete this report successfully.

\section{REFERENCES}

[1] Dinesh K.Sharma, R.K.Jana, Avinash Gaur(2007),Fuzzy Goal Programming Approach for

[2] , N., and Sanquetta, C., “Goal programming in a planning problem”, Applied Mathematics and Agricultural Land Allocation Problem, Yugoslav journal of operations research,31-42

[3] Lee, S.M., Goal Programming for Decision Analysis, Philadelphia, Auerbach Publishers, 1972.

[4] Oliveira, F., Volpi Computation, 140 (2003) 165-178.

[5] Performance Report 2013, Department of Agriculture, Sri Lanka

[6] Performance Report 2012, Department of Agriculture, Sri Lanka

[7] http://www.treasury.gov.lk/news-and-events/557-a-fertilizer-distribution-centre-and-a-fertilizerwarehouse-for-each-agrarian-service-centre.html,2015-04-01

\section{AUTHOR}

Ms. Anuradha Gamage

BSc (Hons) Statistics and Operations Research,

University of Peradeniya, Sri Lanka.

Temporary Tutor in Statistics,

Department of Economics,

University of Ruhuna, Sri Lanka.

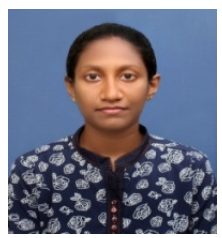

